Prepared in cooperation with the lowa Department of Transportation and the lowa Highway Research Board (Project HR-140)

\title{
Flood of June 30-July 1, 2018, in the Fourmile Creek Basin, near Ankeny, lowa
}

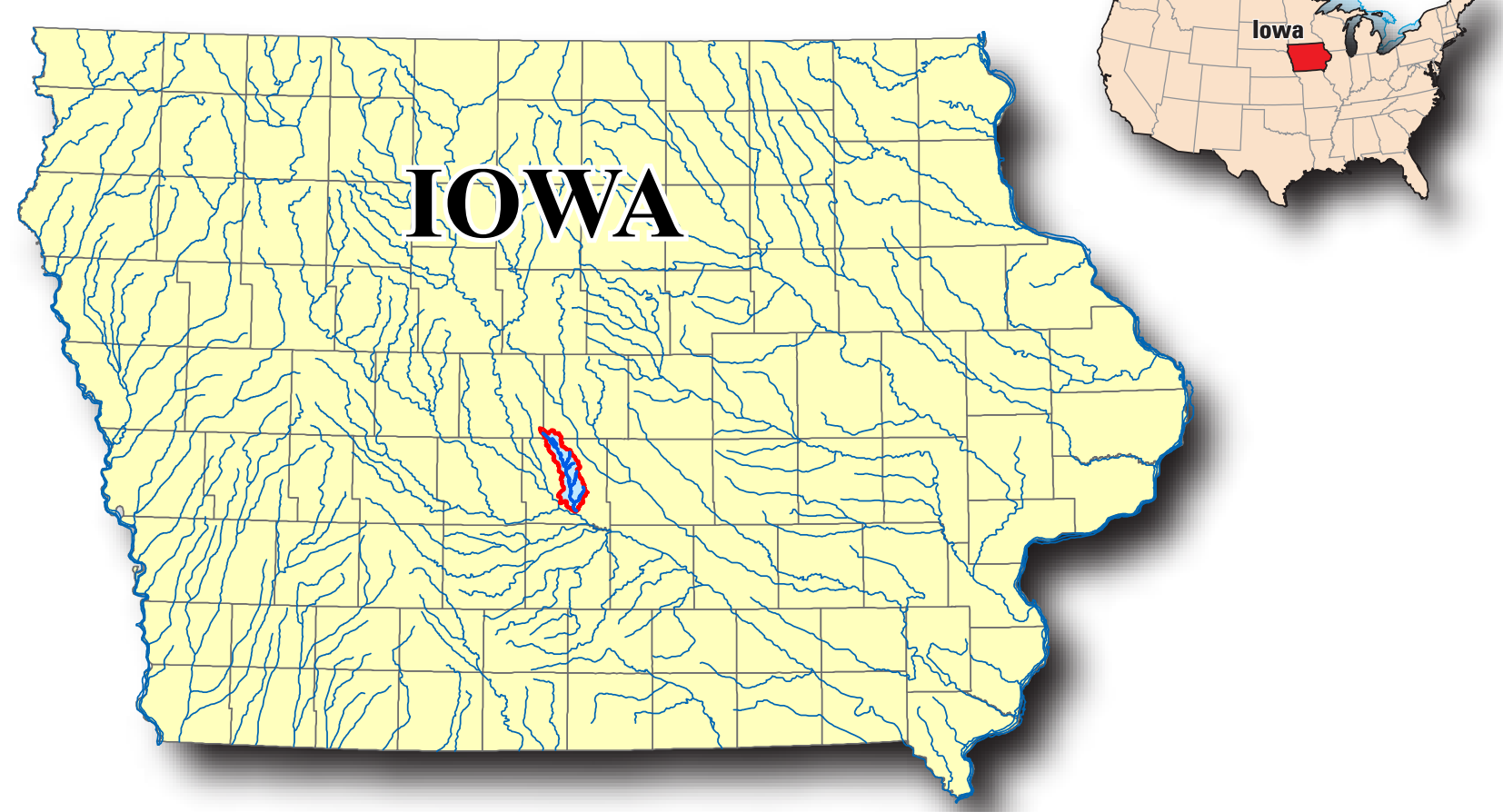

Open-File Report 2021-1044 



\section{Flood of June 30-July 1, 2018, in the Fourmile Creek Basin, near Ankeny, lowa}

By Padraic S. 0'Shea, Jared C. Vegrzyn, and Kimberlee K. Barnes

Prepared in cooperation with the lowa Department of Transportation and the lowa Highway Research Board (Project HR-140)

Open-File Report 2021-1044 


\section{U.S. Geological Survey, Reston, Virginia: 2021}

For more information on the USGS - the Federal source for science about the Earth, its natural and living resources, natural hazards, and the environment—visit https://www.usgs.gov or call 1-888-ASK-USGS.

For an overview of USGS information products, including maps, imagery, and publications, visit https://store.usgs.gov/.

Any use of trade, firm, or product names is for descriptive purposes only and does not imply endorsement by the U.S. Government.

Although this information product, for the most part, is in the public domain, it also may contain copyrighted materials as noted in the text. Permission to reproduce copyrighted items must be secured from the copyright owner.

Suggested citation:

0'Shea, P.S., Vegrzyn, J.C., and Barnes, K.K., 2021, Flood of June 30-July 1, 2018, in the Fourmile Creek Basin, near Ankeny, lowa: U.S. Geological Survey Open-File Report 2021-1044, 18 p., https://doi.org/10.3133/ofr20211044.

Associated data for this publication:

O'Shea, P.S., and Fiala, S.G., 2021, Peak-flow frequency analysis for two selected streamgages in the Fourmile Creek Basin in central lowa, based on data through water year 2018: U.S. Geological Survey data release, https://doi. org/10.5066/P9XZGOG3.

U.S. Geological Survey, 2019, USGS water data for the Nation: U.S. Geological Survey National Water Information System database, https://doi.org/10.5066/F7P55KJN.

ISSN 2331-1258 (online) 


\section{Acknowledgments}

The authors express their gratitude to Lucinda Parker, public information officer, lowa Homeland Security and Emergency Management, for providing public infrastructure storm damage cost estimates.

The authors also recognize U.S. Geological Survey employees Seth Bishop, Jace Cochran, Dave Conell, Eddie Gorman, Doug Hansman, Roger Haschemeyer, Jon Lageman, Ben Metcalf, Seth Meyers, Geoff Montour, Matt Noon, Tyler Rokes, Chris Temeyer, Scott Thul, Clint Van Schepen, and David Warweg for collecting field data for the determination of water-surface and benchmark elevations listed in this report. 



\section{Contents}

Acknowledgments ……...................................................................................................................

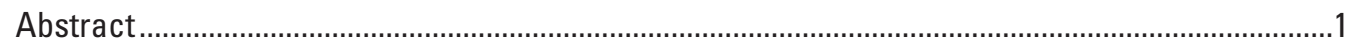

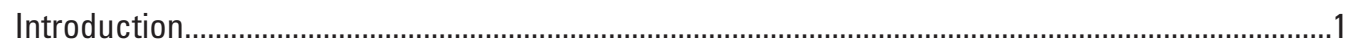

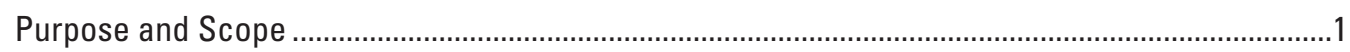

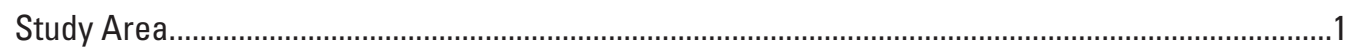

Storm Event.

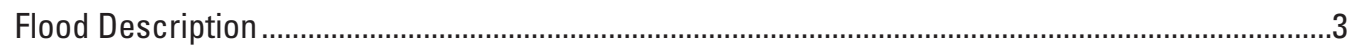

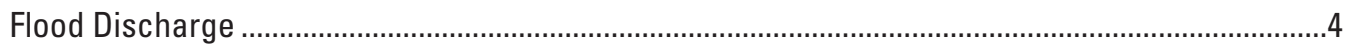

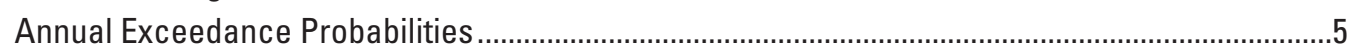

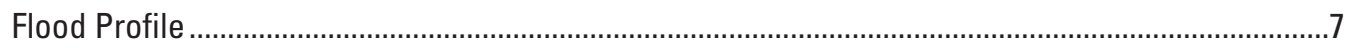

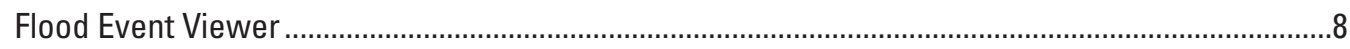

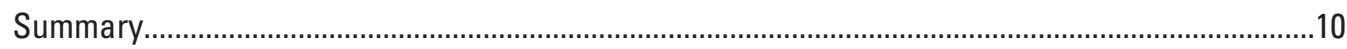

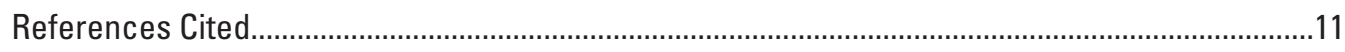

Appendix 1. List of Bench Marks and Reference Points ..............................................................14

\section{Figures}

1. Map showing Fourmile Creek Basin and river reach profile for the flood of

2. Map showing Advanced Hydrologic Prediction Service observed precipitation for lowa on July 1, 2018, with an inset of the Fourmile Creek Basin watershed boundary (National Weather Service, 2018) ......................................................................

3. Discharge hydrographs for June $30-J u l y ~ 2,2018$, with annotated annual exceedance probabilities.

4. Graph showing flood profile of Fourmile Creek, river miles 3.5 to 24.5, June 30

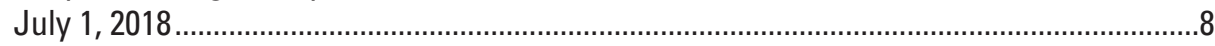

5. Graph showing flood profile of Fourmile Creek, river miles 3.5 to 11.5 , June 30 July 1, 2018

6. Graph showing flood profile of Fourmile Creek, river miles 11.5 to 24.5 , June 30 July 1, 2018

\section{Tables}

1. Maximum stage, discharge, and corresponding annual exceedance-probability range for selected peak flows at streamgages in the Fourmile Creek Basin, central lowa.

2. Annual exceedance probability and equivalent flood-recurrence interval for selected probabilities.

3. Locations and elevations of high-water marks used in the Fourmile Creek flood profile, flood of June 30-July 1, 2018, central lowa. 


\section{Conversion Factors}

U.S. customary units to International System of Units

\begin{tabular}{lll}
\hline \multicolumn{1}{c}{ Multiply } & By & \multicolumn{1}{c}{ To obtain } \\
\hline inch (in.) & Length & \\
foot (ft) & 2.54 & centimeter $(\mathrm{cm})$ \\
mile (mi) & 0.3048 & meter $(\mathrm{m})$ \\
\hline & 1.609 & kilometer $(\mathrm{km})$ \\
\hline square mile $\left(\mathrm{mi}^{2}\right)$ & Area & square kilometer $\left(\mathrm{km}^{2}\right)$ \\
\hline & 2.590 & \\
\hline cubic foot per second $\left(\mathrm{ft}^{3} / \mathrm{s}\right)$ & Flow rate & cubic meter per second $\left(\mathrm{m}^{3} / \mathrm{s}\right)$ \\
\hline
\end{tabular}

\section{Datum}

Elevation or vertical coordinate information is referenced to the North American Vertical Datum of 1988 (NAVD 88). Elevation refers to distance above or below NAVD 88. The NAVD 88 can be converted to the National Geodetic Vertical Datum of 1929 (NGVD 29) by using the National Geodetic Survey conversion utility available at https://www.ngs.noaa.gov/TOOLS/Vertcon/ vertcon.html.

Horizontal coordinate information is referenced to the North American Datum of 1983 (NAD 83).

Map projections are Universal Transverse Mercator, Zone 15.

\section{Supplemental Information}

A water year is the 12-month period from 0 ctober 1 through September 30. The water year is designated by the calendar year in which the water year ends; thus, the water year ending September 30, 2018, is the "2018 water year."

\section{Abbreviations}

$\begin{array}{ll}\text { AEP } & \text { annual exceedance probability } \\ \text { GNSS } & \text { Global Navigation Satellite System } \\ \text { HWM } & \text { high-water mark } \\ \text { NOAA } & \text { National Oceanic and Atmospheric Administration } \\ \text { NWS } & \text { National Weather Service } \\ \text { STN } & \text { Short-Term Network } \\ \text { USGS } & \text { U.S. Geological Survey }\end{array}$




\title{
Flood of June 30-July 1, 2018, in the Fourmile Creek Basin, near Ankeny, lowa
}

\author{
By Padraic S. O'Shea, Jared C. Vegrzyn, and Kimberlee K. Barnes
}

\section{Abstract}

Major flooding occurred June 30-July 1, 2018, in the Fourmile Creek Basin in central Iowa after thunderstorm activity over the region. The largest recorded 24-hour precipitation total at a National Oceanic and Atmospheric Administration weather station was 8.72 inches in Ankeny, Iowa, and 7.54 inches in Des Moines, Iowa. A maximum peak-of-record discharge of 10,000 cubic feet per second was recorded at U.S. Geological Survey streamgage 05485605, Fourmile Creek near Ankeny, Iowa, on July 1, 2018, with an annual exceedance probability of less than 0.2 percent. A maximum peak-of-record discharge of 12,000 cubic feet per second also was recorded at U.S. Geological Survey streamgage 05485640, Fourmile Creek at Des Moines, Iowa, on July 1, 2018, with an annual exceedance-probability range of $0.5-1$ percent. High-water mark elevations were surveyed at 11 locations along Fourmile Creek between State Highway 163 in Pleasant Hill, Iowa, and U.S. Route 69 near Alleman, Iowa, a distance of 21.0 river miles. The high-water marks were used to develop a flood profile for Fourmile Creek.

\section{Introduction}

Intense rainfall contributed to flooding in the Fourmile Creek Basin in central Iowa from June 30 to July 1, 2018. Heavy rainfall totals resulted from thunderstorms, which stalled over the area during the evening of June 30 into the morning hours of July 1 (National Weather Service, 2019a). As a result, many vehicles were stalled or swept away by the flood waters, and many highways were closed throughout the basin. Maximum peak discharges of record were measured at two U.S. Geological Survey (USGS) streamgages along the profiled reach of Fourmile Creek.

\section{Purpose and Scope}

This report is part of an ongoing program of documenting large flood events and the effects of selected highways and bridges on flood levels of rivers and streams in Iowa. The program is funded in cooperation with the Iowa Department of Transportation and the Iowa Highway Research Board (Research Board project HR-140). A list of other Iowa flood profile reports is included in Eash (2014).

This report provides information about the storms and resulting flooding for the 2-day period of June 30-July 1, 2018, in the Fourmile Creek Basin. The estimated annual exceedance-probability (AEP) ranges of the peak flood discharges at two continuous-record streamgages in the Fourmile Creek Basin also are described. High-water marks (HWMs) at selected sites along Fourmile Creek are presented in a flood profile from State Highway 163 in Pleasant Hill, Iowa, to U.S. Route 69, about 2 miles (mi) south of Alleman, Iowa, a distance of 21.0 river miles.

\section{Study Area}

Fourmile Creek is a tributary to the Des Moines River in central Iowa (fig. 1). The Fourmile Creek Basin originates in southeast Boone County, continues in a southeasterly direction through Story County, and flows primarily south through Polk County, Iowa. Fourmile Creek flows through the towns and cities of Slater, Sheldahl, Alleman, Ankeny, Des Moines, and Pleasant Hill, Iowa. Fourmile Creek has five major tributaries: Alleman Creek, Otter Creek, Deer Creek, Muchikinock Creek, and Little Fourmile Creek and flows about $34.5 \mathrm{mi}$ to its mouth at the Des Moines River. The drainage area at the mouth is 120 square miles (Larimer, 1957).

The Fourmile Creek Basin lies mostly in the Des Moines Lobe landform region (96.76 percent), with a small amount of area at the outlet (3.24 percent) in the Southern Iowa Drift Plain. The Des Moines Lobe landform region is characteristic of a young, postglacial landscape that is unique with respect to the rest of the State (Prior, 1991). The Des Moines Lobe generally consists of low relief terrain, accentuated by natural lakes, potholes, and marshes, where surface-water drainage is poorly defined and sluggish. Soils of the Des Moines Lobe generally consist of friable, calcareous loam glacial till with thick deposits of compact, uniform pebbly loam (Oschwald and others, 1965; Prior, 1991). The Southern Iowa Drift Plain is characteristic of an older postglacial landscape that has eroded to form a range of steep to gently rolling topography 


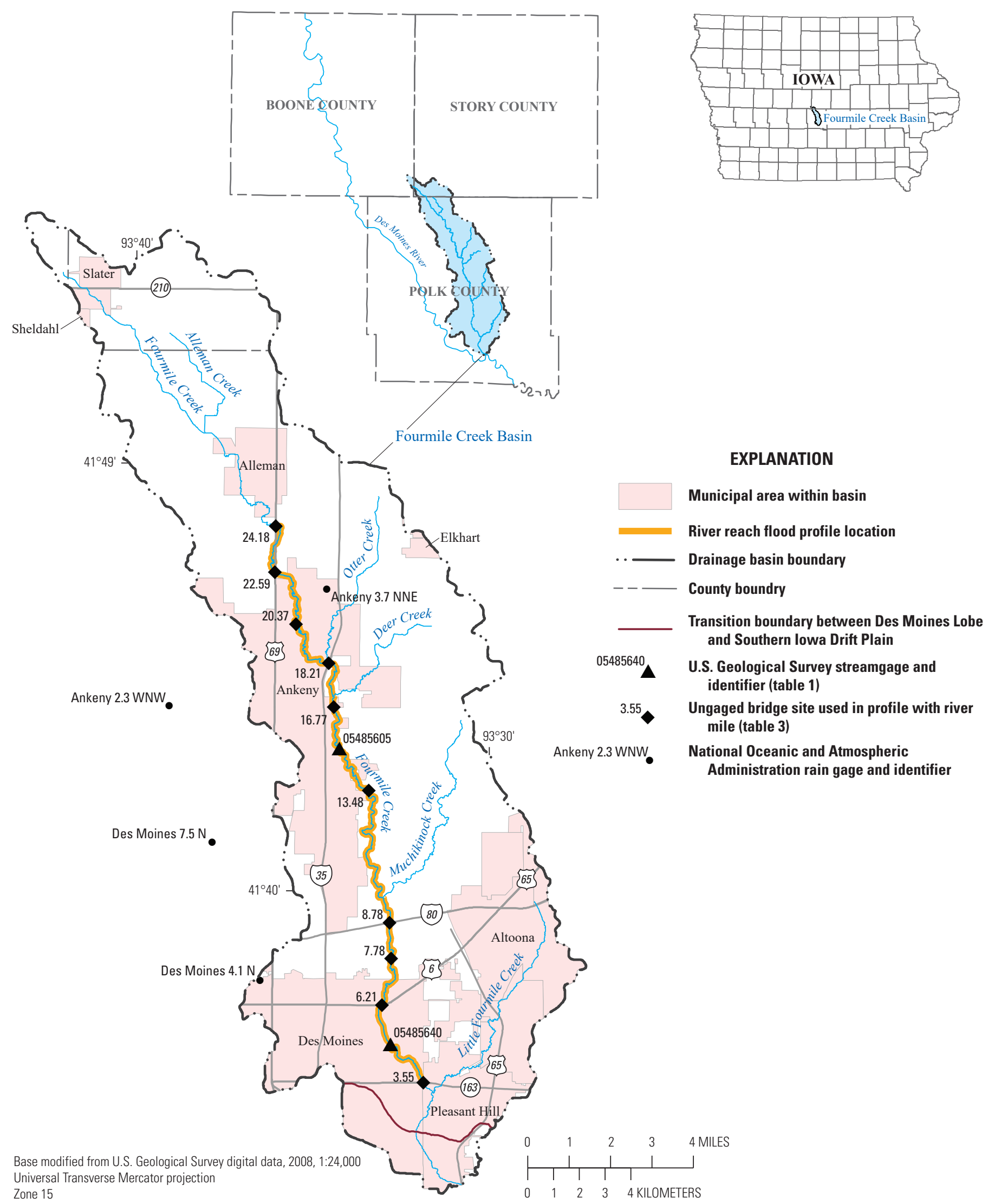

Figure 1. Fourmile Creek Basin and river reach profile for the flood of June 30-July 1, 2018. 
with a well-established drainage system (Prior, 1991). The transition boundary between these two landform regions is in the southern third of Polk County near river mile 1.3 (fig. 1). Extensive descriptions of the landform regions are available from Prior (1991). Based on the 2016 National Land Cover Database (Yang and others, 2018), land cover in the Fourmile Creek Basin is a mix of agriculture (cultivated crops and hay, about 60 percent), low- to high-density development (about 34 percent, of which about 10 percent of this area is classified as 50- to 100-percent impervious), and forest (about 3 percent), with the remaining 3 percent of the area consisting of open water, barren land, shrub/scrub, grassland, and wetlands. An impervious area refers to surfaces such as pavement or building roofs where precipitation can no longer seep into the ground but now runs off into storm sewers or creeks (U.S. Geological Survey, 2020a).

\section{Storm Event}

Thunderstorms, which stalled over parts of central Iowa from June 30 to July 1, 2018, produced localized heavy rainfall totals. The Des Moines metropolitan area received a total of 5-10 inches (in.) of rainfall over the northern half of Polk County from these thunderstorms (National Weather Service, 2019a). Statewide observed precipitation in Iowa on July 1, 2018, is shown in figure 2 (National Weather Service, 2018). A delineation of the Fourmile Creek Basin boundary, in central Iowa, is shown on figure 2 for reference. The National Centers for Environmental Information, which operates under the National Oceanic and Atmospheric Administration (NOAA), maintains a database of environmental data including rainfall from across the Nation (https://www.ncde .noaa.gov/cdo-web/search). At the two NOAA weather stations (designated Ankeny 3.7 NNE and Ankeny 2.3 WNW; fig. 1), weather observers recorded 24-hour precipitation totals of 7.15 and $8.72 \mathrm{in}$., respectively. At the two NOAA weather stations in Des Moines (designated Des Moines 4.1 N and Des Moines 7.5 N; fig. 1), weather observers recorded 24-hour precipitation totals of 5.44 and 7.54 in., respectively (National Oceanic and Atmospheric Administration, National Centers for Environmental Information, 2019). Observation times (the time of day the weather station observer records 24-hour precipitation totals) at the aforementioned NOAA stations were unavailable for this flood event and may differ by station. Observed precipitation totals at each of these stations for the 24-hour period from July 1 to July 2, 2018, were $0 \mathrm{in}$. This event followed the 10th wettest June in Iowa on record. The average statewide rainfall for June 2018 was $7.55 \mathrm{in.} \mathrm{compared} \mathrm{to} \mathrm{the} \mathrm{average} \mathrm{June} \mathrm{rainfall} \mathrm{value} \mathrm{of}$ 4.95 in. for the period 1981 to 2010 (Midwestern Regional Climate Center, 2019). For Iowa, 2018 was one of the wettest years on record, with an average statewide rainfall of 45.08 in., second only to 1993 , which had an average statewide rainfall of 47.88 in. (Midwestern Regional Climate Center 2019). For Des Moines, 2018 was the 12th wettest year on record, with $42.02 \mathrm{in}$. of rain. Waterloo, about $75 \mathrm{mi}$ northeast of the Fourmile Creek Basin, recorded its wettest year on record in 2018 with 54.05 in. of rain (National Weather Service, 2019b).

\section{Flood Description}

Intense rainfall caused flooding in areas of Polk County on June 30-July 1, 2018. As a result of the countywide damages from severe storms, tornadoes, straight-line winds, and flash flooding, Polk County and 30 other counties in Iowa were declared a major disaster area (Federal Emergency Management Agency, 2019). Damages in Polk County exceeded $\$ 15$ million. Of this estimate, more than $\$ 970,000$ were damages to roads and bridges. Damages to public infrastructure exceeded \$11.7 million (Lucinda Parker, Iowa Homeland Security and Emergency Management public information officer, written commun., 2019). Numerous road closures lasted several days beyond the flood peak on July 1. Road closures in Des Moines included Saylor Road, George Flagg Parkway from Southwest 26th Street to Park Avenue, Southwest 30th Street from George Flagg Parkway to Bell Avenue, the Access Road Southeast 14th Court between Hartford Avenue and Granger Avenue, and the 3300 block of Martin Luther King Jr. Parkway. Polk County road closures included multiple locations along 6th Avenue, Southeast Vandalia Drive/Southeast 80th Avenue, Southeast Stewart Drive south of Southeast 56th Avenue, and other temporary closures (not shown in fig. 1). Southbound U.S. Route 65 was closed at Vandalia Road (Polk County Emergency Management Agency, 2018). Dozens of vehicles were stalled or swept away by flood waters during the flash flooding event (National Weather Service, 2019a). Emergency services carried out dozens of high-water rescues of people trapped in flooded homes or vehicles (Davies, 2018). 


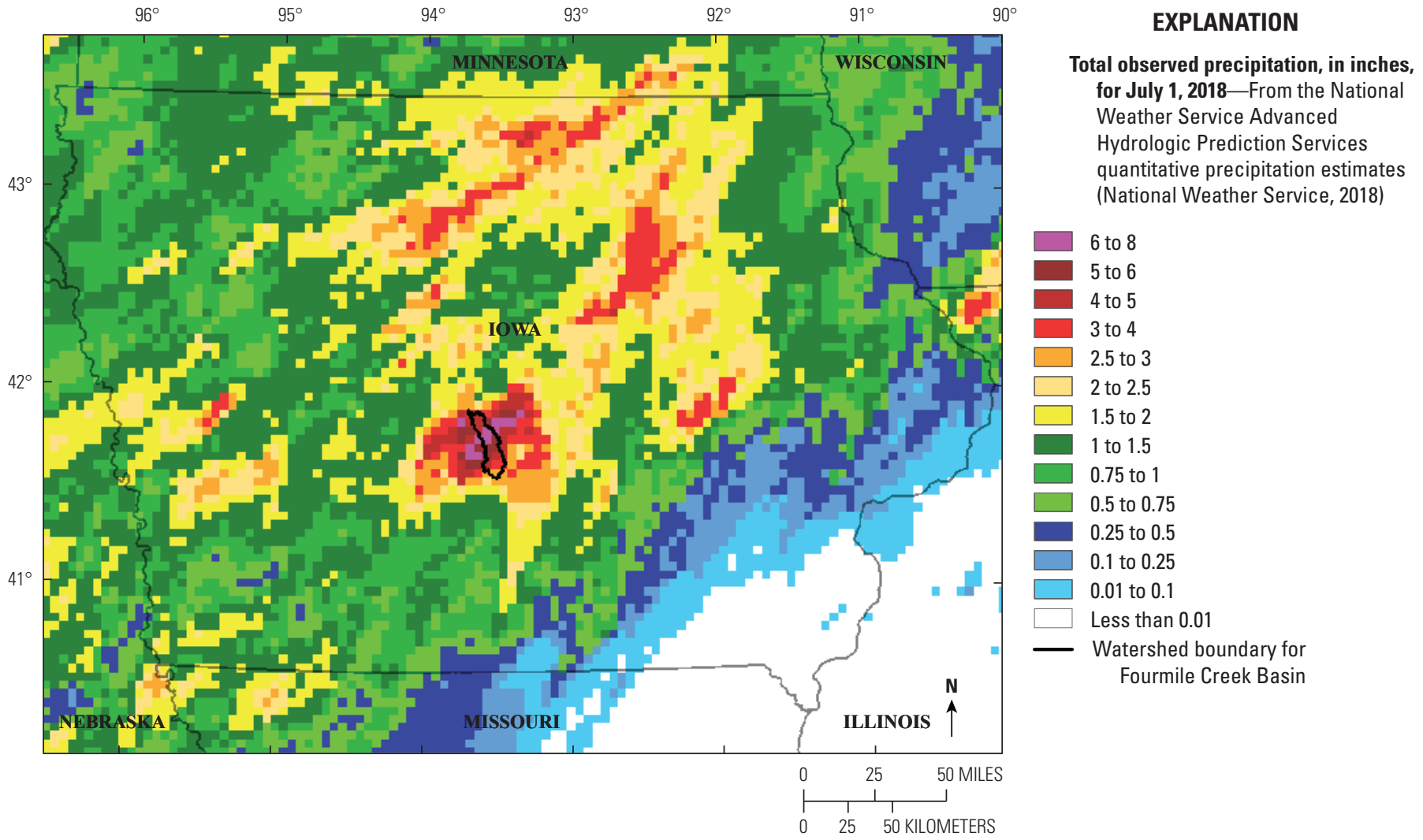

Figure 2. Advanced Hydrologic Prediction Service observed precipitation for lowa on July 1, 2018, with an inset of the Fourmile Creek Basin watershed boundary (National Weather Service, 2018).

\section{Flood Discharge}

At USGS streamgage 05485605, Fourmile Creek near Ankeny, Iowa, the measured discharge changed from a flow of 29 cubic feet per second $\left(\mathrm{ft}^{3} / \mathrm{s}\right)$ and a gage height of 2.39 feet (ft) to its record peak discharge of $10,000 \mathrm{ft}^{3} / \mathrm{s}$ and a gage height of $16.17 \mathrm{ft}$ over the span of 6 hours (U.S. Geological Survey, 2019a). The discharge hydrograph for this streamgage (fig. $3 \mathrm{~A}$ ) shows a span of 2 hours and 30 minutes during the peak of this event where discharge stabilized between 9,910 and $10,000 \mathrm{ft}^{3} / \mathrm{s}$ (U.S. Geological Survey, 2019a). The hydrologic conditions at this streamgage, which resulted in this unusually flat peak, are not known; however, USGS personnel were able to provide independent verification of the recorded peak gage height based on crest-stage gage HWMs collected on the morning of July 1, 2018 (Jason McVay, USGS, written commun., 2020).
At USGS streamgage 05485640, Fourmile Creek at Des Moines, Iowa, the measured discharge changed from $155 \mathrm{ft}^{3} / \mathrm{s}$ and a gage height of $4.59 \mathrm{ft}$ to its record peak discharge of $12,000 \mathrm{ft}^{3} / \mathrm{s}$ and a gage height of $17.51 \mathrm{ft}$ over the span of 8 hours (U.S. Geological Survey, 2019a), and all of this occurred through the middle of the night. The National Weather Service (NWS) flood stage of $12.5 \mathrm{ft}$ was surpassed 2 hours and 15 minutes after the start of the storm (U.S. Geological Survey, 2019a). The discharge and gage height did not fall below the NWS flood stage of $12.5 \mathrm{ft}$ until the evening of July 1, 2018, 22 hours and 45 minutes after the flood stage was exceeded (fig. 3B) (U.S. Geological Survey, 2019a). The peak discharge at this streamgage was determined from a stage-discharge rating curve and was verified by a discharge measurement made by USGS personnel near the time of occurrence for the peak. 


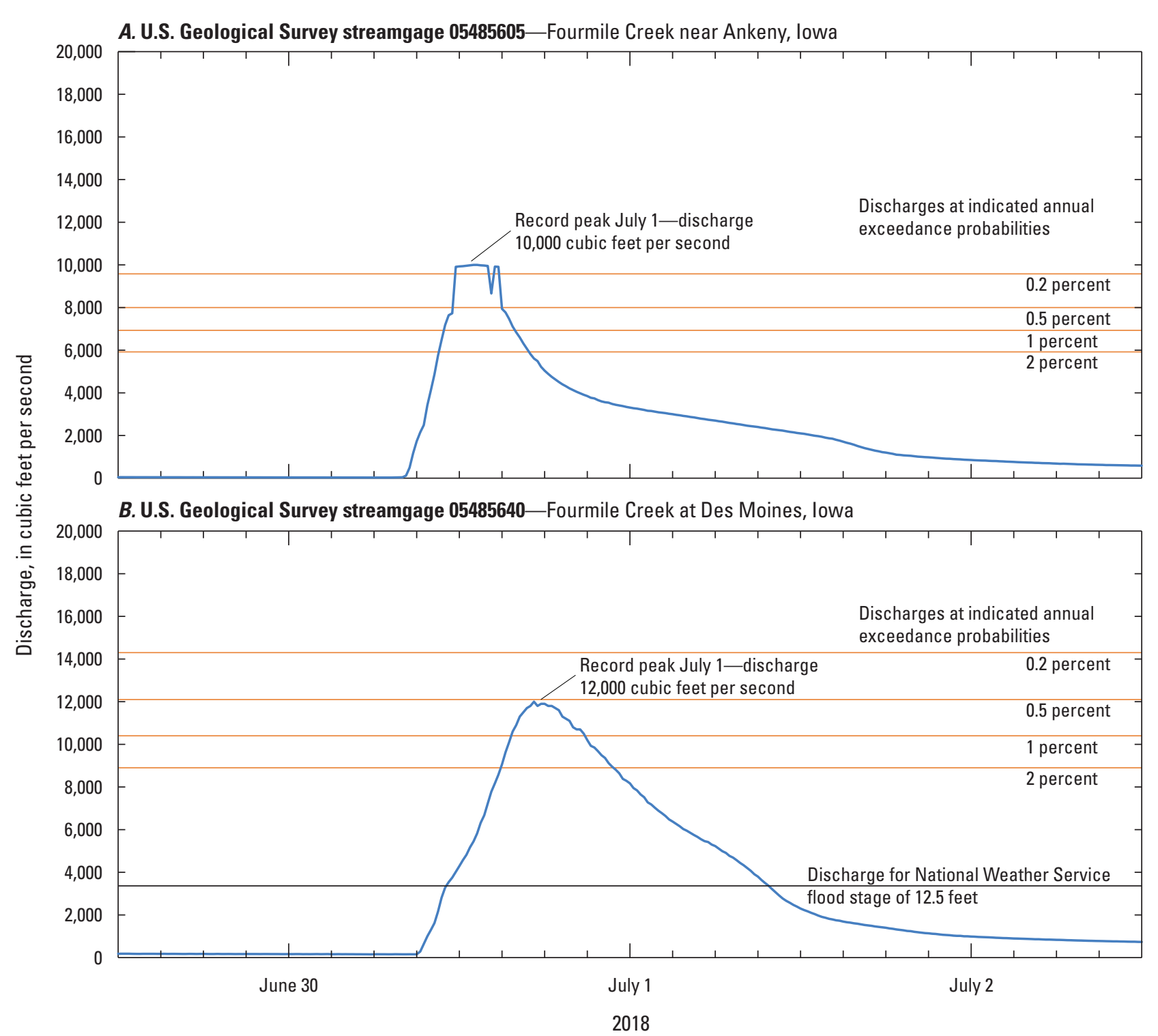

Figure 3. Discharge hydrographs for June 30-July 2, 2018, with annotated annual exceedance probabilities. $A$, Fourmile Creek near Ankeny, lowa; $B$, Fourmile Creek at Des Moines, lowa.

\section{Annual Exceedance Probabilities}

The 2018 flood-peak discharges for the two streamgages are listed in table 1. Selected prior-year peak discharges are included in the table for comparison purposes. Also included in table 1 are AEP ranges for the maximum peak discharges at both Fourmile Creek streamgages. The AEP is an estimate of the likelihood of a flood of specific magnitude occurring in any given year, and an AEP range expresses the uncertainty of estimating precise exceedance probabilities. The reporting ranges are greater than 10 percent, $4-10$ percent, 2-4 percent, 1-2 percent, $0.5-1$ percent, $0.2-0.5$ percent, and less than 0.2 percent (Eash, 2001). The range is determined by the estimated AEP discharges that bracket the observed flood-peak discharge. If the observed peak discharge is the same value as an estimated AEP discharge, the lower AEP range is used.

The estimated 2-, 1-, 0.5-, and 0.2-percent AEP discharges at streamgages 05485605 , Fourmile Creek near Ankeny, and 05485640, Fourmile Creek at Des Moines, are represented as horizontal lines (fig. 3); the AEP ranges are the areas between the lines. The probability discharges for the two streamgages were calculated as weighted independent estimates of the atsite flood-frequency quantiles with quantile estimates obtained by regional regression equations following guidelines in appendix 9 of Bulletin 17C (England and others, 2017) and are available as a USGS data release (O'Shea and Fiala, 2021). 
Table 1. Maximum stage, discharge, and corresponding annual exceedance-probability range for selected peak flows at streamgages in the Fourmile Creek Basin, central lowa.

$\left[\mathrm{mi}^{2}\right.$, square mile; ft, foot; $\mathrm{ft}^{3} / \mathrm{s}$, cubic foot per second; AEP, annual exceedance probability; >, greater than; <, less than]

\begin{tabular}{|c|c|c|c|c|c|c|}
\hline Streamgage number and name & $\begin{array}{l}\text { Peak-flow record } \\
\text { (water years) }\end{array}$ & $\begin{array}{c}\text { Drainage } \\
\text { area } \\
\left(\mathrm{mi}^{2}\right)\end{array}$ & Date of peak & $\begin{array}{c}\text { Peak } \\
\text { stage } \\
(\mathrm{ft})\end{array}$ & $\begin{array}{c}\text { Peak } \\
\text { discharge } \\
\left(\mathrm{ft}^{3} / \mathrm{s}\right)\end{array}$ & $\begin{array}{c}\text { AEP range }^{1} \\
\text { (percent) }\end{array}$ \\
\hline \multirow{3}{*}{$\begin{array}{l}\text { 05485605, Fourmile Creek near Ankeny, } \\
\text { Iowa, DS1 }\end{array}$} & \multirow[t]{3}{*}{$2004-18$} & \multirow[t]{3}{*}{62.0} & $7 / 28 / 2008$ & 12.19 & 3,050 & $>10$ \\
\hline & & & $8 / 11 / 2010$ & 12.98 & 4,730 & $4-10$ \\
\hline & & & $7 / 1 / 2018$ & 16.17 & 10,000 & $<0.2$ \\
\hline $\begin{array}{l}\text { 05485640, Fourmile Creek at Des } \\
\text { Moines, Iowa }\end{array}$ & $\begin{array}{l}1972-79 \\
1981-2018\end{array}$ & 92.7 & $7 / 1 / 2018$ & 17.51 & 12,000 & $0.5-1$ \\
\hline
\end{tabular}

\footnotetext{
${ }^{1}$ AEP ranges reflect the uncertainty of estimating flood-frequency discharges. The exceedance probability is calculated using established techniques but then reported in one of the following ranges: greater than 10 percent, $4-10$ percent, $2-4$ percent, $1-2$ percent, $0.5-1$ percent, $0.2-0.5$ percent, and less than 0.2 percent. The AEP ranges are based on the weighted independent estimates of the at-site flood-frequency quantiles with estimates obtained by regional regression equations following guidelines in appendix 9 of Bulletin 17C (England and others, 2017).
}

Exceedance probabilities were formerly reported as flood probabilities, or flood-recurrence intervals, expressed in years. A 1-percent AEP discharge is the same as the 100-year recurrenceinterval flood discharge. Because of confusion caused over the years by two or more "100-year floods" occurring in a period of much less than 100 years, the scientific and engineering community has begun expressing the annual likelihood of occurrence of flood discharges as a probability (Holmes and Dinicola, 2010). The percentage of probability is the inverse of the recurrence interval multiplied by 100 . Selected AEPs and equivalent flood-recurrence intervals are listed in table 2.

For informational purposes, discharges corresponding to NWS designated flood stages (fig. 3) also are shown on the hydrographs when available. The flood stages represent "an established gage height for a given location at which a rise in water-surface level begins to create a hazard to lives, property, or commerce" (National Weather Service, 2019c, p. 3). The discharges corresponding to the NWS flood stages were determined from the respective USGS stagedischarge rating curves in use at the time of the flood. At streamgage 05485640, Fourmile Creek at Des Moines, the NWS flood stage is $12.5 \mathrm{ft}$ (National Weather Service, 2020a) and the discharge is $3,360 \mathrm{ft}^{3} / \mathrm{s}$ (U.S. Geological Survey, 2020b). At streamgage 05485605, Fourmile Creek near Ankeny, the NWS has no established flood stage (National Weather Service, 2020b).

Table 2. Annual exceedance probability and equivalent flood-recurrence interval for selected probabilities.

\begin{tabular}{cc}
\hline $\begin{array}{c}\text { Annual exceedance probability } \\
\text { (percent) }\end{array}$ & $\begin{array}{c}\text { Flood-recurrence interval } \\
\text { (years) }\end{array}$ \\
\hline 20 & 5 \\
10 & 10 \\
4 & 25 \\
2 & 50 \\
1 & 100 \\
0.5 & 200 \\
0.2 & 500 \\
\hline
\end{tabular}




\section{Flood Profile}

The USGS located and surveyed the elevations of HWMs at 11 locations along Fourmile Creek to develop a flood profile (fig. 1, table 3). The profile is 21.0 river miles from (a little more than 3 mi upstream from) the mouth of Fourmile Creek to U.S. Route 69, 2 mi south of Alleman, Iowa. The HWM locations include all Federal and State Highway bridges and several county and local road bridges.

The HWMs were located and marked within 2 days of the flood. The HWMs were located on the upstream and downstream sides of the bridges. The upstream marks were located about one bridge length upstream from the bridge to avoid drawdown effects from channel contraction, and the downstream marks were located immediately downstream from the bridge. During August 14-17, 2018, the HWMs were surveyed to a either a temporary bench mark or an Iowa Department of Transportation established bench mark at each location. Bridge-deck, low-bridge chord, and low-flow reference point elevations also were measured with respect to the bench marks. The low-flow reference points were established so that water-surface elevations could be measured during a period when the discharge was not directly affected by rainfall. All published elevations are referenced to the North American Vertical Datum of 1988 and are given in appendix 1.
The locations of HWMs are measured in river miles from the mouth of Fourmile Creek where it flows into the Des Moines River (table 3). The upstream distances from the Des Moines River to the measured HWMs were determined using geographic information system software using the USGS National Hydrography Dataset data (U.S. Geological Survey, 2019b). The HWM elevations along Fourmile Creek are plotted in a flood profile (fig. 4). The flood profile is expanded to show greater detail and annotate locations relative to the measured HWMs (figs. 5-6). The listed HWM distances and elevations (table 3 ) and values used to create the flood profiles (figs. 4-6) are averages of multiple upstream and downstream HWMs measured at each location. The line connecting the HWMs in the figures is a straight-line interpolation and approximates the high-water surface between the marks. The low-flow line also is a straight-line interpolation meant to estimate the water surface between HWM locations.

Only bridges where HWMs were measured are shown in the figures. They are symbolized by an I-beam symbol where the bottom flange represents the lowest elevation of the lowbridge chord and the top flange represents the elevation of the bridge deck. The vertical lines along the bottom of the figures also show locations of roads and bridges where HWMs were measured. Selected landmarks also are shown (figs. 4-6) for reference.

Table 3. Locations and elevations of high-water marks used in the Fourmile Creek flood profile, flood of June 30-July 1, 2018, central lowa.

[HWM, high-water mark; NAVD 88, North American Vertical Datum of 1988; ND, not determined; E, East; USGS, U.S. Geological Survey; NE, Northeast; SE, Southeast]

\begin{tabular}{clcc}
\hline $\begin{array}{c}\text { Distance from mouth } \\
\text { (river miles) }\end{array}$ & \multicolumn{1}{c}{ Location } & $\begin{array}{c}\text { Downstream HWM } \\
\text { (feet above NAVD 88) }\end{array}$ & $\begin{array}{c}\text { Upstream HWM } \\
\text { (feet above NAVD 88) }\end{array}$ \\
\hline 3.18 & Mouth of Little Fourmile Creek & ND & ND \\
\hline 3.55 & State Highway 163 (E University Ave), Pleasant Hill & 801.88 & 804.76 \\
\hline 5.16 & USGS streamgage 05485640, Easton Blvd (County Road F56), Des & 813.02 & 814.45 \\
& Moines & & 822.86 \\
\hline 6.21 & U.S. Highway 6 (E Euclid Ave), Des Moines & 820.30 & 833.17 \\
\hline 7.78 & E Broadway Ave (NE 46th Ave), Des Moines & 830.32 & 838.02 \\
\hline 8.78 & Interstate 80, Des Moines & 835.92 & ND \\
\hline .49 & Mouth of Muchikinock Creek & ND & 872.84 \\
13.48 & SE Oralabor Road (NE 78th Ave/County Road F38), Ankeny & 870.47 & ND \\
\hline 15.35 & USGS streamgage 05485605, NE 86th Ave, east of Ankeny & 8981.11 & 891.39 \\
\hline 16.77 & Enterprise Road (E 1st Street), Ankeny & 890.95 & ND \\
\hline 17.06 & Mouth of Deer Creek & ND & 901.06 \\
\hline 18.21 & Interstate 35, Ankeny & 898.61 & ND \\
\hline 18.31 & Mouth of Otter Creek & ND & 913.14 \\
\hline 2.37 & NE 36th Street, Ankeny & 907.73 & 928.78 \\
\hline 22.59 & U.S. Route 69 (Ankeny Blvd/NE 14th Street), north of Ankeny & 927.30 & 938.32 \\
\hline 2.18 & U.S. Route 69 (Ankeny Blvd/NE 14th Street), south of Alleman & 938.92 & \\
\hline
\end{tabular}

\footnotetext{
${ }^{1}$ This HWM elevation was derived from the recorded stage data at USGS streamgage 05485605, Fourmile Creek near Ankeny, Iowa, DS1. No HWM elevations were surveyed at this location.
} 


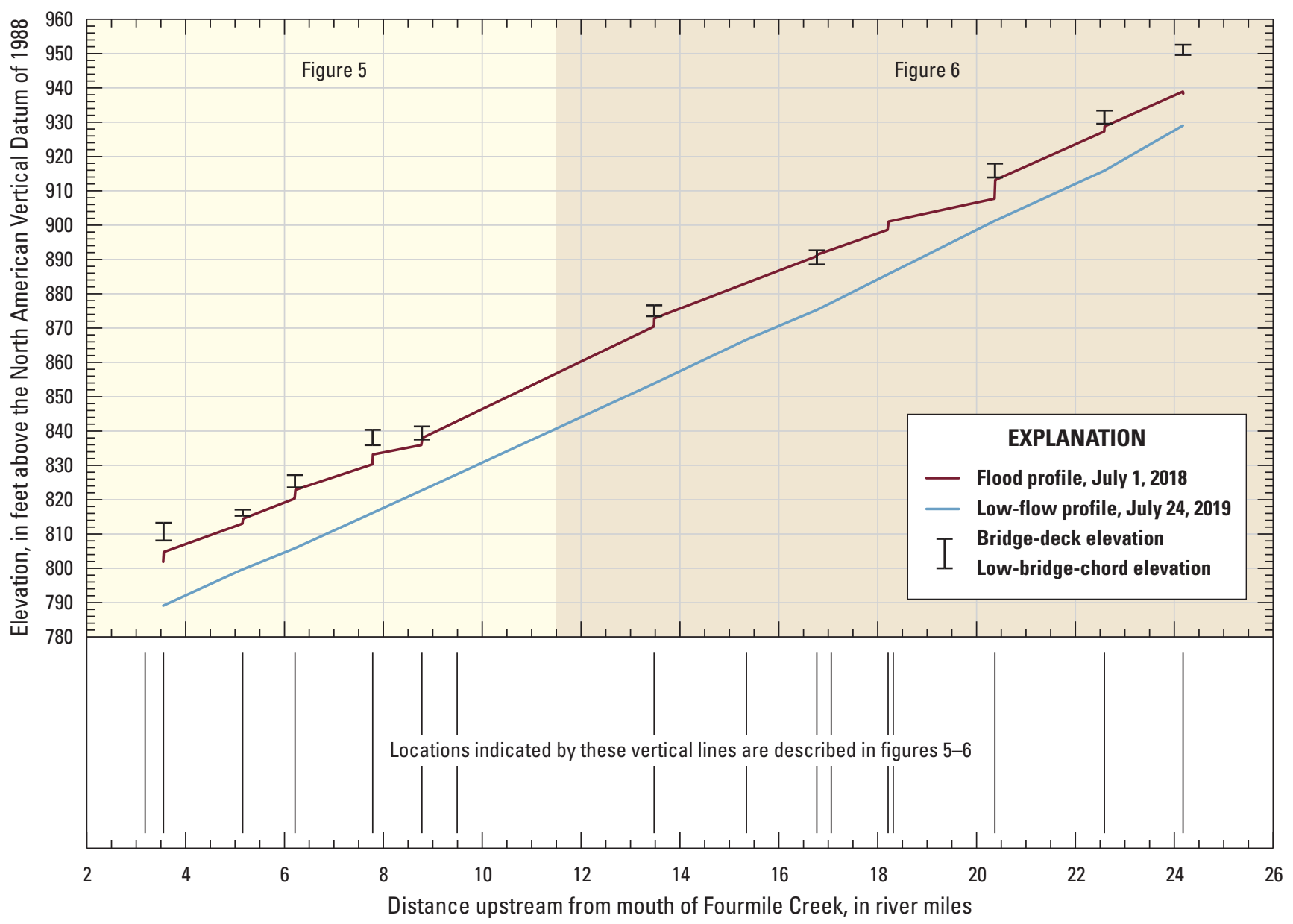

Figure 4. Flood profile of Fourmile Creek, river miles 3.5 to 24.5, June 30-July 1, 2018.

\section{Flood Event Viewer}

The USGS plays an important role in the collection and delivery of data resulting from coastal and inland flooding events. The data collected from surveyed HWM elevations are stored in the Short-Term Network (STN) database (https://stn.wim.usgs.gov/STNWeb/). The USGS developed the STN database, and an accompanying set of tools, to facilitate the collection and dissemination of event-based flood data. Data can be viewed in the Flood Event Viewer, a mapcentric data portal that allows users to explore and download sensor data and HWM records for any event in the STN database, including historical high-water events dating back more than 40 years (Jenter and others, 2017). The HWM elevations collected for this report are incorporated in the USGS Flood Event Viewer online data portal (https://stn.wim.usgs.gov/ FEV/) under the Iowa June-July 2018 flood. 


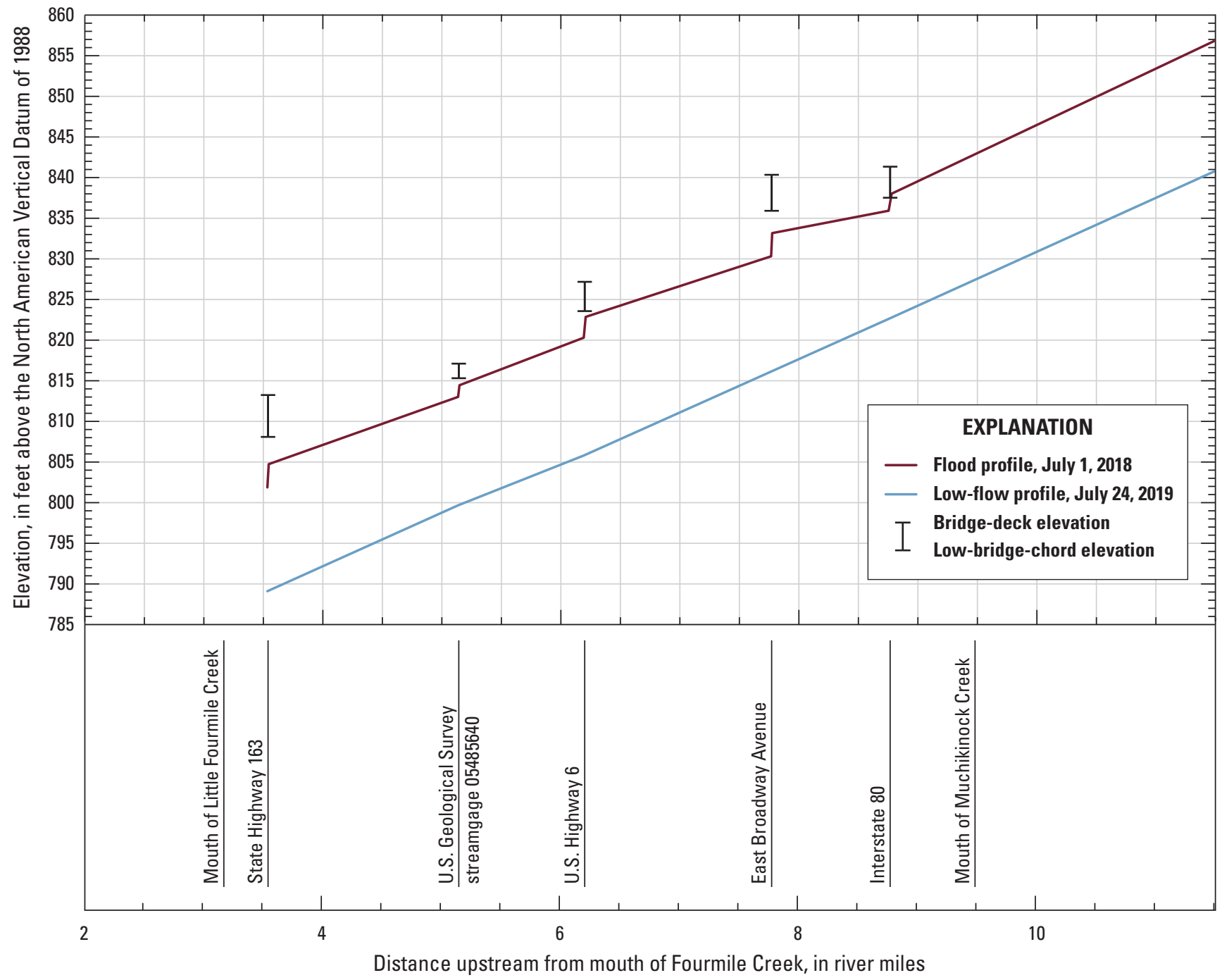

Figure 5. Flood profile of Fourmile Creek, river miles 3.5 to 11.5, June 30-July 1, 2018. 


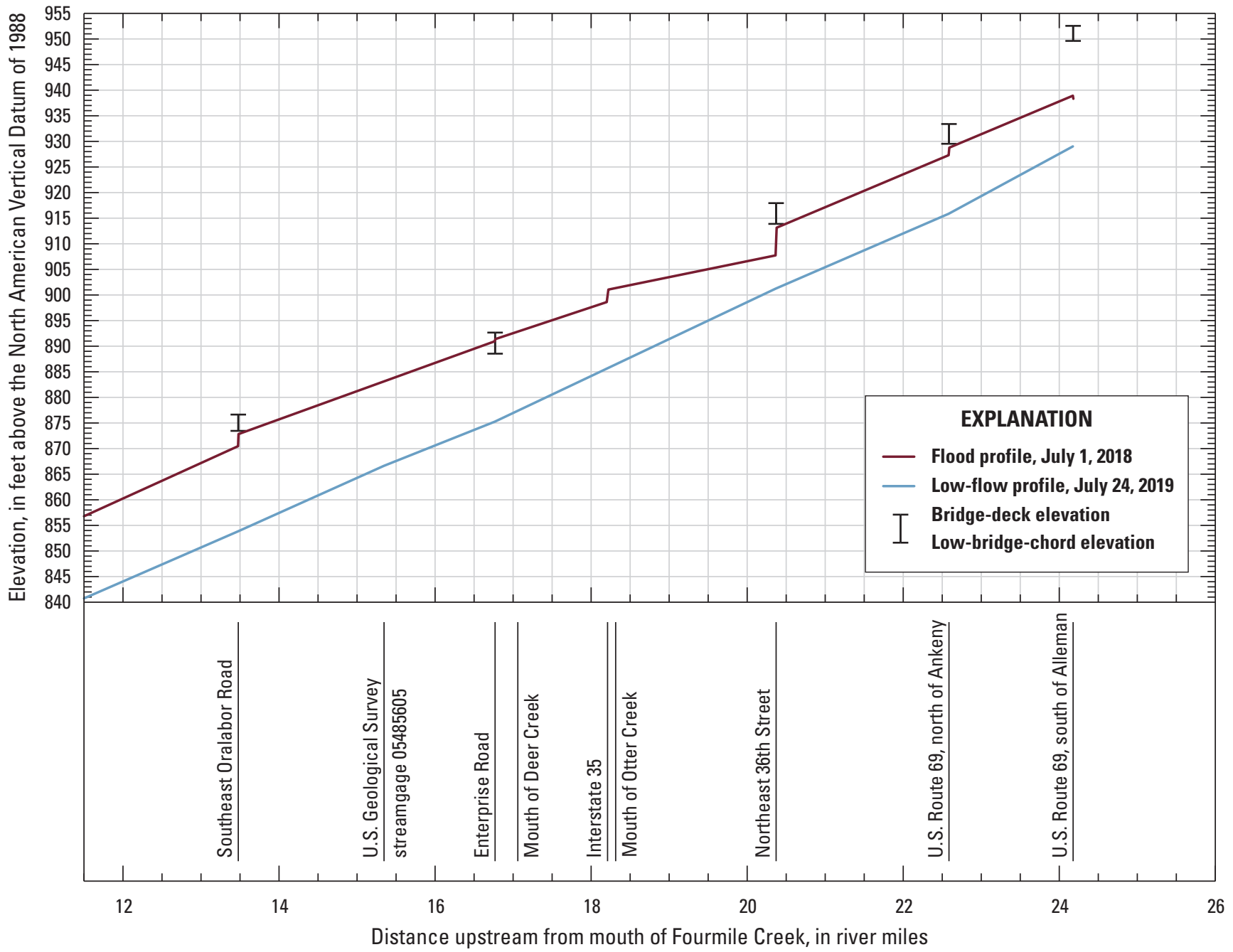

Figure 6. Flood profile of Fourmile Creek, river miles 11.5 to 24.5, June 30-July 1, 2018.

\section{Summary}

The Fourmile Creek Basin in central Iowa flooded over a 2-day period from June 30 to July 1, 2018, after thunderstorm activity over central Iowa. The largest recorded 24-hour precipitation total at a National Oceanic and Atmospheric Administration weather station was 8.72 inches in Ankeny, Iowa, and 7.54 inches in Des Moines, Iowa. Along the profiled reach, a maximum peak-of-record discharge of 12,000 cubic feet per second was measured at U.S. Geological Survey streamgage 05485640, Fourmile Creek at Des Moines, Iowa, on July 1, 2018. The annual exceedance-probability range of the peak discharge is $0.5-1$ percent. A maximum peak-ofrecord discharge of 10,000 cubic feet per second also was measured at U.S. Geological Survey streamgage 05485605, Fourmile Creek near Ankeny, Iowa, on July 1, 2018. The annual exceedance probability of the peak discharge is less than 0.2 percent. High-water marks measured at 11 locations along Fourmile Creek were used to create a flood profile between U.S. Route 69, about 2 miles south of Alleman, Iowa, and State Highway 163 in Pleasant Hill, Iowa, a distance of 21.0 river miles. 


\section{References Cited}

Davies, R., 2018, USA-Deadly floods in Des Moines, Iowa: FloodList web page, accessed October 28, 2019, at http://floodlist.com/america/usa/floods-des-moines-iowajune-2018.

Eash, D.A., 2001, Techniques for estimating flood-frequency discharges for streams in Iowa: U.S. Geological Survey Water-Resources Investigations Report 2000-4233, 88 p. [Also available at https://doi.org/10.3133/wri004233.]

Eash, D.A., 2014, Summary of U.S. Geological Survey reports documenting flood profiles of streams in Iowa, 1963-2012: U.S. Geological Survey Scientific Investigations Report 2014-5085, 32 p. [Also available at https://doi.org/10.3133/ sir20145085.]

England, J.F., Jr., Cohn, T.A., Faber, B.A., Stedinger, J.R., Thomas, W.O., Jr., Veilleux, A.G., Kiang, J.E., and Mason, R.R., Jr., 2017, Guidelines for determining flood flow frequency-Bulletin 17C: U.S. Geological Survey Techniques and Methods, book 4, chap. B5, 168 p., accessed April 21, 2020, at https://doi.org/10.3133/tm4B5.

Federal Emergency Management Agency, 2019, Iowa severe storms, tornadoes, straight-line winds, and flooding (DR-4386-IA): Federal Emergency Management Agency web page, accessed October 28, 2019, at https://www .fema.gov/disaster/4386.

Holmes, R.R., Jr., and Dinicola, K., 2010, 100-year floodIt's all about chance: U.S. Geological Survey General Information Product 106, 1 p., accessed April 21, 2020, at https://doi.org/10.3133/gip106.

Jenter, H., Koenig, T., Mason, R., and Peppler, M., 2017, Event-based flood data collection and dissemination-The USGS Flood Event Viewer and Short-Term Network database: U.S. Geological Survey, Office of Surface Water, 1 p., accessed July 27, 2020, at https://www.ofcm.gov/meetings/ TCORF/ihc17/Posters/P07\%20Jenter\%20STN\%20Da tabase.pdf.

Larimer, O.J., 1957, Drainage areas of Iowa streams: Iowa Highway Research Board Bulletin no. 7 (reprinted in 1974), 433 p. [Also available at https://www.iowadot.gov/ research/reports/Year/2003andolder/fullreports/HR-29\%20 FINAL\%20Drainage\%20Areas\%20of\%20Iowa\%20S treams.pdf.]

Midwestern Regional Climate Center, 2019, cli-MATEMRCC Application Tools Environment: Midwestern Regional Climate Center digital database, accessed October 28, 2019, at https://mrcc.illinois.edu/CLIMATE/.
National Oceanic and Atmospheric Administration, National Centers for Environmental Information, 2019, Climate data online: National Oceanic and Atmospheric Administration digital data, accessed October 28, 2019, at https://www.ncdc .noaa.gov/cdo-web/search.

National Weather Service, 2018, Advanced Hydrologic Prediction Service, QPE-Quantitative precipitation estimates: National Oceanic and Atmospheric Administration digital data, accessed December 9, 2019, at https://water.we ather.gov/precip/.

National Weather Service, 2019a, June 30, 2018, Central Iowa major flash flood event: National Oceanic and Atmospheric Administration web page, accessed October 28, 2019, at https://www.weather.gov/dmx/20180630_EpicFlashFlood.

National Weather Service, 2019b, 2018 —Wet year at both Waterloo and Des Moines: National Oceanic and Atmospheric Administration web page, accessed October 28, 2019, at https://www.weather.gov/dmx/ 2018Precipitation.

National Weather Service, 2019c, Water resources information on the web-A manual for users: National Oceanic and Atmospheric Administration, 43 p., accessed April 21, 2020, at https://www.weather.gov/media/owlie/Water\%2 0Resources\%20Web\%20Products\%20Manual.pdf.

National Weather Service, 2020a, Advanced Hydrologic Prediction Service-Fourmile Creek (Central IA) at Des Moines Easton Blvd: National Oceanic and Atmospheric Administration web page, accessed April 21, 2020, at https://water.weather.gov/ahps2/hydrograph.php?wfo= dmx\&gage $=$ dfmi 4 .

National Weather Service, 2020b, Advanced Hydrologic Prediction Service-Fourmile Creek (Central IA) near Ankeny NE 86th Ave: National Oceanic and Atmospheric Administration web page, accessed April 21, 2020, at https://water.weather.gov/ahps2/hydrograph.php?wfo= dmx\&gage $=$ anki4 .

Oschwald, W.R., Riecken, F.F., Dideriksen, R.I., Scholtes, W.H., and Schaller, F.W., 1965, Principal soils of Iowa: Ames, Iowa, Iowa State University, Department of Agronomy, Special Report no. 42, 77 p.

O'Shea, P.S., and Fiala, S.G., 2021, Peak-flow frequency analysis for two selected streamgages in the Fourmile Creek Basin in central Iowa, based on data through water year 2018: U.S. Geological Survey data release, https://doi.org/ 10.5066/P9XZGOG3. 
Polk County Emergency Management Agency, 2018, Situation report (SIT-REP) version 3-Summer 2018 flooding: Polk County Emergency Management, 12 p., accessed October 28, 2019, at https://www.polkcountyiowa.gov/ media/5slpk5jj/sitrep-20180701.pdf.

Prior, J.C., 1991, Landforms of Iowa: Iowa City, Iowa, University of Iowa Press, $154 \mathrm{p}$.

U.S. Geological Survey, 2019a, USGS water data for the Nation: U.S. Geological Survey National Water Information System database, accessed August 28, 2019, at https://doi.org/10.5066/F7P55KJN.

U.S. Geological Survey, 2019b, National Hydrography Dataset: U.S. Geological Survey web page, accessed June 7, 2019, at https://nhd.usgs.gov/NHD_High_Resolution.html.

U.S. Geological Survey, 2020a, Impervious surfaces and flooding: U.S. Geological Survey web page, accessed May 21, 2020, at https://www.usgs.gov/special-topic/waterscience-school/science/impervious-surfaces-and-flooding? qt-science_center_objects $=0 \#$ qt-science_center_objects.
U.S. Geological Survey, 2020b, U.S. Geological Survey National Water Information System database, accessed April 21, 2020, at https://waterdata.usgs.gov/nwisweb/get ratings?file_type $=$ exsa\&site_no $=05485640$.

Yang, L., Jin, S., Danielson, P., Homer, C., Gass, L., Bender, S.M., Case, A., Costello, C., Dewitz, J., Fry, J., Funk, M., Grannemann, B., Licknes, G.C., Rigge, M., and Xian, G., 2018, A new generation of the United States National Land Cover Database-Requirements, research priorities, design, and implementation strategies: ISPRS Journal of Photogrammetry and Remote Sensing, v. 146, p. 108-123. [Also available at https://doi.org/10.1016/j.isprsjprs.2 018.09.006.] 
Appendix 


\section{Appendix 1. List of Bench Marks and Reference Points}

The U.S. Geological Survey (USGS) used the bench marks, temporary bench marks, and reference points listed in table 1.1 to facilitate measuring and referencing the elevations of high-water marks (HWMs), low-flow water surfaces, bridge decks, and low-bridge chords. All bench mark, temporary bench mark, and reference point elevations listed in appendix table 1.1 are referenced to the North American Vertical Datum of 1988. The temporary bench marks were established at sites where bench marks were not available. In general, bench marks are points that were specifically designed to mark an elevation, such as USGS elevation disks and Iowa Department of Transportation bench marks (round top rods embedded in concrete at one or more corners of a bridge). Marks - such as chiseled squares, chiseled arrows, concrete anchors, or file marks-were used as temporary bench marks or reference points. Reference points were established above water on the downstream side of each bridge to facilitate measuring low-flow watersurface elevations. Users are cautioned that the bench marks, temporary bench marks, and reference points used for this flood profile may have been altered or destroyed since being used in 2018.

The bench marks, temporary bench marks, and reference points are listed in upstream to downstream order. The bench marks, temporary bench marks, and reference points are identified by an index number composed of the Public Land Survey System township, range, section number, and quarter section for each location; for example, T81N R24W 25 SW means "township 81 north, range 24 west, section 25, southwest quarter section." Where two or more bench marks/ reference points are in the same location, the points are distinguished by a sequence number in parentheses. The terms "right" and "left" in the description refer to the side of the river determined as viewed while facing in the downstream direction.

USGS survey crews established bench mark, temporary bench mark, and reference point elevations (table 1.1) using a Global Navigation Satellite System (GNSS) approach with the objective to achieve a level II or level III quality category survey as referenced from Rydlund and Densmore (2012). The GNSS survey approach involved real-time positioning using the Iowa Real-Time Network SmartNET, a GNSS reference station network service provided by the Iowa Department of Transportation and Leica Geosystems (Iowa Department of Transportation, 2018), and suitable published bench marks to provide checks and localizations for resulting GNSS-derived bench mark, temporary bench mark, and reference point elevations. Bench mark check ins and check outs along with "blunder checks" were completed as outlined in Rydlund and Densmore (2012). In the absence of suitable published bench marks, deviations were taken from referenced level II and level III protocols such that a hybrid approach was developed with redundant observations to provide an element of quality assurance. Differential and trigonometric leveling were used to perpetuate elevation from fiducial monuments to the HWMs. Differential leveling followed procedures and closure requirements as referenced from Kenney (2010). A modified trigonometric leveling approach using a total station also was used, ensuring all backsight and foresight checks were within 0.10 foot (ft) among an open loop traverse.

GNSS Iowa Real-Time Network SmartNET surveys used to establish bench mark, temporary bench mark, and reference point elevations in table 1.1 represented uncertainties that were derived from published bench marks. These published marks were used to localize and constrain GNSS observations for many of the temporary bench mark and reference point elevations whereas others were simply used to check elevations. Overall uncertainty for the bench marks and reference points in table 1.1 ranged from 0.10 to $0.35 \mathrm{ft}$. Subsequent HWM uncertainties ranged from 0.05 to $0.4 \mathrm{ft}$, as disseminated within the Flood Event Viewer (https://stn.wim.usgs.gov/FEV/) with accompanying metadata. 
Table 1.1. Bench marks and reference points used in the Fourmile Creek flood profile, flood of June 30-July 1, 2018, central lowa.

[Bench marks and reference points are listed in upstream order. Where two or more bench marks/reference points are in the same location, the points are distinguished by a sequence number, in parentheses. NAVD 88, North American Vertical Datum of 1988; TBM, temporary bench mark; GNSS, Global Navigation Satellite System; RP, reference point; NE, Northeast; DOT, Department of Transportation; SE, Southeast; USGS, U.S. Geological Survey; E, East; BM, bench mark]

\begin{tabular}{|c|c|c|c|c|c|}
\hline $\begin{array}{l}\text { Public Land Survey System } \\
\text { (township, range, section, } \\
\text { quarter section, sequence } \\
\text { number at same location) }\end{array}$ & $\begin{array}{c}\text { Mark } \\
\text { classification }\end{array}$ & Location & Mark & $\begin{array}{c}\text { Elevation } \\
\text { (feet above } \\
\text { NAVD 88) }\end{array}$ & $\begin{array}{l}\text { Elevation } \\
\text { determination } \\
\text { method }\end{array}$ \\
\hline T81N R24W 25 SW (1) & TBM & $\begin{array}{l}\text { About } 2.0 \text { miles south of Alleman, on U.S. Route } 69 \text { bridge } \\
\text { over Fourmile Creek, on right downstream side of bridge. }\end{array}$ & Chiseled $\mathrm{x}$ & 954.69 & GNSS \\
\hline T81N R24W 25 SW (2) & $\mathrm{RP}$ & $\begin{array}{l}\text { About } 2.0 \text { miles south of Alleman, on U.S. Route } 69 \text { bridge } \\
\text { over Fourmile Creek, on downstream side of bridge deck } \\
\text { between } 8 \text { th and 9th drain hole from right side of bridge. }\end{array}$ & Chiseled square & 952.61 & GNSS \\
\hline T81N R24W 35 SE (1) & TBM & $\begin{array}{l}\text { About } 3.0 \text { miles south of Alleman, on U.S. Route } 69 \text { bridge } \\
\text { over Fourmile Creek, on right downstream side of bridge. }\end{array}$ & Chiseled $\mathrm{x}$ & 936.36 & GNSS \\
\hline T81N R24W 35 SE (2) & $\mathrm{RP}$ & $\begin{array}{l}\text { About } 3.0 \text { miles south of Alleman, on U.S. Route } 69 \text { bridge } \\
\text { over Fourmile Creek, on downstream side of bridge deck. }\end{array}$ & Chiseled square & 933.88 & GNSS \\
\hline T80N R24W 1 SE (1) & TBM & $\begin{array}{l}\text { About } 1.5 \text { miles north of Ankeny, on NE } 36 \text { th Street bridge } \\
\text { over Fourmile Creek, on left downstream wall. }\end{array}$ & Chiseled $\mathrm{x}$ & 920.68 & GNSS \\
\hline T80N R24W 1 SE (2) & $\mathrm{RP}$ & $\begin{array}{l}\text { About } 1.5 \text { miles north of Ankeny, on NE 36th Street bridge } \\
\text { over Fourmile Creek, on downstream wall. }\end{array}$ & Chiseled square & 921.20 & GNSS \\
\hline T80N R23W 7 SW (1) & $\mathrm{BM}$ & $\begin{array}{l}\text { About } 1.0 \text { mile east of Ankeny, on Interstate } 35 \text { bridge over } \\
\text { Fourmile Creek, on left upstream side of bridge. }\end{array}$ & Iowa DOT bench mark & 907.15 & GNSS \\
\hline T80N R23W 7 SW (2) & TBM & $\begin{array}{l}\text { About } 1.0 \text { mile east of Ankeny, on Interstate } 35 \text { bridge over } \\
\text { Fourmile Creek, on right downstream side of bridge. }\end{array}$ & Chiseled square & 906.18 & GNSS \\
\hline T80N R23W 7 SW (3) & $\mathrm{RP}$ & $\begin{array}{l}\text { About } 1.0 \text { mile east of Ankeny, on Interstate } 35 \text { bridge over } \\
\text { Fourmile Creek, on right downstream side of bridge. }\end{array}$ & 3 chiseled marks & 906.38 & GNSS \\
\hline T80N R23W 19 NW (1) & TBM & $\begin{array}{l}\text { About } 1.5 \text { miles east of Ankeny, Enterprise Road bridge over } \\
\text { Fourmile Creek, on right downstream side of bridge. }\end{array}$ & Chiseled square & 895.32 & GNSS \\
\hline T80N R23W 19 NW (2) & $\mathrm{RP}$ & $\begin{array}{l}\text { About } 1.5 \text { miles east of Ankeny, Enterprise Road bridge over } \\
\text { Fourmile Creek, on downstream bridge deck. }\end{array}$ & Chiseled square & 893.53 & GNSS \\
\hline T80N R23W 19 SE (1) & $\mathrm{RP}$ & $\begin{array}{l}\text { About } 1.5 \text { miles east of Ankeny, site of streamgage } \\
05485605 \text { Fourmile Creek near Ankeny, on NE 86th } \\
\text { Avenue bridge over Fourmile Creek, on downstream } \\
\text { handrail at station } 48 .\end{array}$ & 3 chiseled marks & 884.22 & $\begin{array}{l}\text { Streamgage } \\
\text { elevation data }\end{array}$ \\
\hline T80N R23W 29 SW (1) & TBM & $\begin{array}{l}\text { About } 1.5 \text { miles east of Oralabor, SE Oralabor Road bridge } \\
\text { over Fourmile Creek, on top of left downstream wall. }\end{array}$ & $\begin{array}{l}\text { 3/8-inch anchor and USGS } \\
\text { washer }\end{array}$ & 879.36 & GNSS \\
\hline T80N R23W 29 SW (2) & $\mathrm{RP}$ & $\begin{array}{l}\text { About } 1.5 \text { miles east of Oralabor, SE Oralabor Road } \\
\text { bridge over Fourmile Creek, set in downstream guardrail } \\
\text { between } 27 \text { th and } 28 \text { th vertical from right side of bridge. }\end{array}$ & 3 chiseled marks & 879.46 & GNSS \\
\hline
\end{tabular}


[Bench marks and reference points are listed in upstream order. Where two or more bench marks/reference points are in the same location, the points are distinguished by a sequence number, in parentheses. NAVD 88, North American Vertical Datum of 1988; TBM, temporary bench mark; GNSS, Global Navigation Satellite System; RP, reference point; NE, Northeast; DOT, Department of Transportation; SE, Southeast; USGS, U.S. Geological Survey; E, East; BM, bench mark]

\begin{tabular}{|c|c|c|c|c|c|}
\hline $\begin{array}{l}\text { Public Land Survey System } \\
\text { (township, range, section, } \\
\text { quarter section, sequence } \\
\text { number at same location) }\end{array}$ & $\begin{array}{c}\text { Mark } \\
\text { classification }\end{array}$ & Location & Mark & $\begin{array}{c}\text { Elevation } \\
\text { (feet above } \\
\text { NAVD 88) }\end{array}$ & $\begin{array}{l}\text { Elevation } \\
\text { determination } \\
\text { method }\end{array}$ \\
\hline T79N R23W 17 NE (1) & TBM & $\begin{array}{l}\text { About } 3.0 \text { miles east of Marquisville on Interstate } 80 \text { bridge } \\
\text { over Fourmile Creek, set vertically in right downstream } \\
\text { wall. }\end{array}$ & $\begin{array}{l}\text { 3/8-inch anchor and USGS } \\
\text { washer }\end{array}$ & 843.16 & GNSS \\
\hline T79N R23W 17 NE (2) & $\mathrm{RP}$ & $\begin{array}{l}\text { About } 3.0 \text { miles east of Marquisville on Interstate } 80 \text { bridge } \\
\text { over Fourmile Creek, set horizontally in face of wall } \\
100 \text { feet from right downstream side of bridge. }\end{array}$ & $\begin{array}{l}\text { 3/8-inch anchor and USGS } \\
\text { washer }\end{array}$ & 842.17 & GNSS \\
\hline T79N R23W 17 SE (1) & TBM & $\begin{array}{l}\text { About } 3.0 \text { miles east of Marquisville on E Broadway Avenue } \\
\text { bridge over Fourmile Creek, on top of left upstream wall. }\end{array}$ & $\begin{array}{l}\text { Chiseled triangle and circle } \\
\text { plug }\end{array}$ & 842.97 & GNSS \\
\hline T79N R23W 17 SE (2) & $\mathrm{RP}$ & $\begin{array}{l}\text { About } 3.0 \text { miles east of Marquisville on E Broadway Avenue } \\
\text { bridge over Fourmile Creek, set horizontally in down- } \\
\text { stream wall } 40 \text { feet from left side of bridge. }\end{array}$ & $\begin{array}{l}\text { 3/8-inch anchor and USGS } \\
\text { washer }\end{array}$ & 842.92 & GNSS \\
\hline T79N R23W 29 NE (1) & TBM & $\begin{array}{l}\text { At Des Moines on Highway } 6 \text { bridge over Fourmile Creek, } \\
\text { set vertically in upstream side of wall between } 2 \mathrm{~d} \text { and } 3 \mathrm{~d} \\
\text { steel verticals. }\end{array}$ & 3/8-inch anchor & 830.95 & GNSS \\
\hline T79N R23W 29 NE (2) & $\mathrm{RP}$ & $\begin{array}{l}\text { At Des Moines on Highway } 6 \text { bridge over Fourmile Creek, } \\
\text { on downstream deck of bridge between 12th and 13th } \\
\text { vertical. }\end{array}$ & 3 chiseled marks & 827.19 & GNSS \\
\hline T79 R23W 32 NE (1) & TBM & $\begin{array}{l}\text { At Des Moines, site of streamgage } 05485640 \text {, Fourmile } \\
\text { Creek at Des Moines, on Easton Boulevard bridge over } \\
\text { Fourmile Creek, on fence bolt head on right downstream } \\
\text { side of bridge closest to the streamgage. }\end{array}$ & Chiseled cross & 817.15 & GNSS \\
\hline T79 R23W 32 NE (2) & $\mathrm{RP}$ & $\begin{array}{l}\text { At Des Moines, site of streamgage } 05485640 \text {, Fourmile } \\
\text { Creek at Des Moines, on Easton Boulevard bridge over } \\
\text { Fourmile Creek, on fence support tab first vertical left of } \\
\text { the wire weight. }\end{array}$ & 3 chiseled marks & 817.26 & GNSS \\
\hline T78N R23W 5 NE (1) & $\mathrm{BM}$ & $\begin{array}{l}\text { At Pleasant Hill, on State Highway } 163 \text { bridge over Fourmile } \\
\text { Creek, on left downstream side of bridge. }\end{array}$ & Iowa DOT bench mark & 815.48 & GNSS \\
\hline T78N R23W 5 NE (2) & $\mathrm{BM}$ & $\begin{array}{l}\text { At Pleasant Hill, on State Highway } 163 \text { bridge over Fourmile } \\
\text { Creek, on right downstream side of bridge. }\end{array}$ & USGS BM & 823.56 & GNSS \\
\hline T78N R23W 5 NE (3) & $\mathrm{BM}$ & $\begin{array}{l}\text { At Pleasant Hill, on State Highway } 163 \text { bridge over Fourmile } \\
\text { Creek, on left upstream side of bridge. }\end{array}$ & Iowa DOT bench mark & 816.18 & GNSS \\
\hline T78N R23W 5 NE (4) & $\mathrm{BM}$ & $\begin{array}{l}\text { At Pleasant Hill, on State Highway } 163 \text { bridge over Fourmile } \\
\text { Creek, on right upstream side of bridge. }\end{array}$ & Iowa DOT bench mark & 825.94 & GNSS \\
\hline
\end{tabular}


Table 1.1. Bench marks and reference points used in the Fourmile Creek flood profile, flood of June 30-July 1, 2018, central lowa.-Continued

Bench marks and reference points are listed in upstream order. Where two or more bench marks/reference points are in the same location, the points are distinguished by a sequence number, in parentheses. NAVD 88, North American Vertical Datum of 1988; TBM, temporary bench mark; GNSS, Global Navigation Satellite System; RP, reference point; NE, Northeast; DOT, Department of Transportation; SE, Southeast; USGS, U.S. Geological Survey; E, East; BM, bench mark]

\begin{tabular}{|c|c|c|c|c|c|}
\hline $\begin{array}{l}\text { Public Land Survey System } \\
\text { (township, range, section, } \\
\text { quarter section, sequence } \\
\text { number at same location) }\end{array}$ & $\begin{array}{c}\text { Mark } \\
\text { classification }\end{array}$ & Location & Mark & $\begin{array}{l}\text { Elevation } \\
\text { (feet above } \\
\text { NAVD 88) }\end{array}$ & $\begin{array}{l}\text { Elevation } \\
\text { determination } \\
\text { method }\end{array}$ \\
\hline T78N R23W 5 NE (5) & $\mathrm{BM}$ & $\begin{array}{l}\text { At Pleasant Hill, on State Highway } 163 \text { bridge over } \\
\text { Fourmile Creek, Iowa DOT Plug } \# 891 \text {. }\end{array}$ & Iowa DOT bench mark & 890.73 & GNSS \\
\hline T78N R23W 5 NE (6) & $\mathrm{RP}$ & $\begin{array}{l}\text { At Pleasant Hill, on State Highway } 163 \text { bridge over } \\
\text { Fourmile Creek, on downstream wall } 100 \text { feet from right } \\
\text { side of bridge (high point). }\end{array}$ & 3 chiseled marks & 819.38 & GNSS \\
\hline
\end{tabular}




\section{References Cited}

Iowa Department of Transportation, 2018, Iowa Real-Time Network: Iowa Department of Transportation web page, accessed August 28, 2019, at https://iowadot.gov/rtn/iartnresources/about-the-iartn.

Kenney, T.A., 2010, Levels at gaging stations: U.S. Geological Survey Techniques and Methods, book 3, chap. A19, 60 p., accessed October 2020 at https://doi.org/10.3133/tm3A19.
Rydlund, P.H., Jr., and Densmore, B.K., 2012, Methods of practice and guidelines for using survey-grade global navigation satellite systems (GNSS) to establish vertical datum in the United States Geological Survey: U.S. Geological Survey Techniques and Methods, book 11, chap. D1, 102 p. with appendixes. [Also available at https://doi.org/10.3133/ tm11D1.] 
For more information about this publication, contact: Director, USGS Central Midwest Water Science Center 400 South Clinton Street, Suite 269

lowa City, IA 52240

319-337-4191

For additional information, visit: https://www.usgs.gov/ centers/cm-water

Publishing support provided by the

Rolla Publishing Service Center 


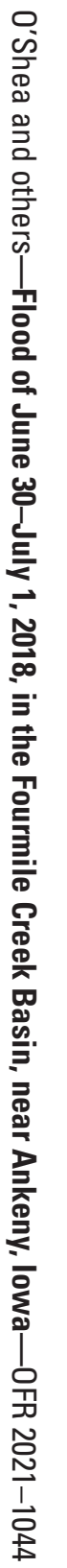

